[計測自 動制 御 学 会論文集

Lol.55, No.2, 92/99 (2019)

\title{
段階的な最適化計算とグラフ分割を用いた鉄道乗務員スケジュールの作成 一大規模かつ複雑な構造をもつ路線への適用一
}

\author{
鎌田龍 太**渡邊亮* \\ Railway Crew Scheduling Based on Step by Step Optimization and Graph Partitioning \\ -Application to Large-scale and Complex Railway Route- \\ Ryuta KAmAta* and Ryo WatAnABE*
}

\begin{abstract}
A railway crew scheduling problem is an assignment problem of crews for a given operational schedule under the constraint on labor regulations. In this paper, we discuss an automatic railway crew scheduling method based on numerical optimization for a large-scale and complex railway route with branch lines and multiple bases. The proposed method makes the crew schedule automatically using step by step optimization based on a partial pairing, an elastic embedded set partitioning problem and a graph partitioning.
\end{abstract}

Key Words: crew scheduling, elastic embedded set partitioning problem, step by step optimization, graph partitioning

1.はじめに

鉄道は，旅客や貨物の輸送に広く利用されている。都市部 の鉄道に対する旅客の需要は非常に高く，通勤ラッシュ時に 扔ける列車の運行本数は増加傾向にある. 列車の運行には運 転士と車掌の組である乗務員をすべての列車に配置する必要 があるが，乗務員の労働条件に関する制約を考慮した効率的 な乗務員運用計画を作成することは容易ではない ${ }^{1)}$ 。この乗 務員運用計画は乗務員スケジュールとよばれ，一般にダイヤ 改正前に 1 2 か月かけて手作業で作成されている.作成者 の経験と力量によりスケジュールの質と作成時間が左右され ることから，最適な乗務員スケジュールの自動作成が求めら れている.

鉄道における乗務員スケジュールの作成は，一般に「乗務員 スケジューリング問題 ${ }^{1}$ ～3)」とよばれる問題の一種で, 多く の先行研究に技いて「行路案（スケジュールの候補）の作成」 と「行路案の最適化」の 2 つのステップにより問題の解決が 図られている. 行路案は, 乗務員が担当する業務の最小単位 である乗務の組み合わせで構成される，先行研究 ${ }^{4)}$ では, 問 題の計算規模を縮小寸るために, 行路案を少数の乗務から構 成される「部分行路」を用いて段階的に作成する手法が提案 されている. しかし，支線を有さない基地数が 1 駅の路線を

* 早稲田大学先進理工学部 東京都新宿区大久保 3-4-1

* School of Advanced Science and Engineering, Waseda University, 3-4-1 Okubo, Shinjuku-ku, Tokyo

(Received July 25, 2018)

(Revised October 22, 2018)
対象としているため, 大規模かつ複雑な構造をもつ路線に対 する手法の有効性は未検証である ${ }^{4), 5)}$. 本稿では, 高橋ら ${ }^{4)}$ によって提案された部分行路を用いる手法に, Graves ら ${ }^{6)}$ より定式化されたペナルティ付き集合分割問題, Jütte ら 7 ) が用いたグラフ分割，および支線と複数基地に関する従来手 法の改良を導入した新しい行路案作成手法を提案する.

本稿の構成は下記のとおりである. 2 章では乗務員スケ ジューリング問題の概要について述べる．3 章では本稿が提 案する乗務員スケジュールの作成方法について述べる．4 章で は支線と複数基地への対応について述べる５章では実際の首 都圈大手私鉄路線の運行ダイヤを対象とした数值実験を行な い, 提案手法の有効性を検証する. 最後に, 6 章でまとめる.

\section{2. 乗務員スケジューリング問題}

\section{1 用語の定義}

本稿で用いる用語について，その定義を述べる. ダイヤグラム：列車の運行計画を表わした図表．列車の出発 駅, 出発時刻, 到着駅, 到着時刻などが与えられている. 乗務員: 列車を運行する運転士 1 名と車掌 1 名の組. 支線：鉄道路線において, 本線から分岐する路線. 交代可能駅：乗務員の列車の乗り継ぎが可能な駅. 基地：出勤, 退勤, 休憩が行なわれる交代可能駅. 宿泊駅：仮眠が行なわれる交代可能駅. 分岐駅: 本線から支線へ分岐する起点となる交代可能駅. 乗務：ダイヤグラムを交代可能駅で分割したもの. 乗務員の 担当する業務の最小単位.

行路：乗務員が業務開始から業務終了までの間に担当する乗 


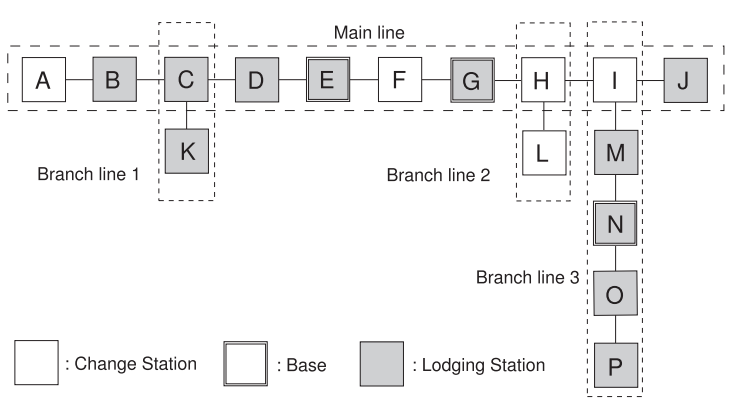

Fig. 1 Railway route

務の集合.

部分行路：少数の乗務によって構成される時間的に連続した 行路の一部分.

便乗：同一の列車に 2 組以上の乗務員が乗り合わせている状 態. 片方の乗務員は業務をせずに移動のために乗車.

乗り継ぎ時間：前乗務の到着時刻から次乗務の出発時刻まで の時間.

休輴時間：乗り継ぎ時間が規定時間を超えた場合に休㮩時間 として扱う。

勤務時間 : 行路における最初の乗務開始時刻から最後の乗務 終了時刻までの時間.

日勤：勤務が 1 歴日に収まる勤務形態.

泊り明け：勤務が 2 歴日にまたがる勤務形態.

\section{2 対象とする路線}

本稿が対象とする首都圈大手私鉄路線の概略図を Fig. 1 に 示す. Fig. 1 は全 68 駅のうち, 16 駅の交代可能駅の位置関 係を表わしている，基地は 3 駅，宿泊駅は 11 駅，分岐駅は 3 駅ある. A 駅から J 駅までの本線のほかに, C 駅から K 駅 までの支線 $1, \mathrm{H}$ 駅から L 駅までの支線 2 , I 駅から P 駅ま での支線 3 がある。列車種別は普通や各種の特急などがあり， 勤務形態は日勤と泊り明けがある。また，勤務時間や休㮩時 間などに関する労働条件が存在する（路線の詳細は 5.1 節に 記述).

\section{3 乗務員スケジューリング問題}

乗務員スケジューリング問題とは，与えられたダイヤグラ ムに対して乗務員の労働条件に関する制約のもと，すべての 列車に乗務員を配置する問題である. 多くの先行研究におい て「行路案 (行路の候補) の作成」と「行路案の最適化」の 2 つ のステップにより効率的な人員配置の実現を図るアプローチ が議論されている。また，乗務員の労働条件に関する制約は 行路案の作成に㧍いて，すべての列車に乗務員を配置する制 約は行路案の最適化で考慮されている.

行路案の作成には，事前にすべての行路案を用意する「事 前列挙型」と必要に応じて行路案を生成する「列生成型」の 2 つのアプローチが存在する ${ }^{3)}$. 事前列挙型 $\left.{ }^{8)}, 9\right)$ は深さ優先 探索法などを用いて全探索する方法であり，列生成型 10),11) は列生成子問題の最適化により目的関数值を改善する行路案 （列）のみを生成する方法である.
行路案の最適化では, 乗務員スケジューリング問題は集合 被覆問題 (set covering problem) あるいは集合分割問題 (set partitioning problem）として定式化される ${ }^{3)} . M$ を乗務の 集合, $N$ を行路案の集合とする. 行路案 $j \in N$ を列 $\boldsymbol{a}_{j}$ で 表わし，乗務 $i \in M$ を含むとき $a_{i j}=1$ （そうでなければ $\left.a_{i j}=0\right)$ とする. $c_{j}$ は行路案 $j$ のコストを表わす (3.3 節). 決定変数 $x_{j}$ は行路案 $j$ の採否を表わす $0-1$ 変数である.こ のとき, 集合被覆問題は (1) (3) 式で記述される.

$$
\begin{array}{ll}
\min & z=\sum_{j \in N} c_{j} x_{j} \\
\text { s.t. } & \sum_{j \in N} a_{i j} x_{j} \geq 1, \quad \forall i \in M \\
& x_{j} \in\{0,1\}, \quad \forall j \in N
\end{array}
$$

(1) 式は目的関数值 $z$ を最小化する問題であることを，(2) 式 は各乗務に 1 組以上の乗務員を割り当てる制約条件を表わす. (2) 式が等式制約の場合は集合分割問題と呼ばれ，便乗を許 容しない問題となるために実行可能解が存在しない場合があ る. 集合被覆問題の求解には既存の数理計画ソルバーを用い るのが一般的であることから, 多くの先行研究では行路案の 作成手法が議論の中心となっている.

\section{4 先行研究における行路案作成のアプローチ}

事前列挙型は労働条件を満たすすべての行路案を作成する が, 乗務の総数が多くなるほど行路案の数が澎大となるため, 有限時間内の作成が困難となることに加えて最適化計算に支 障を生ずる．現在の主流である列生成型のアプローチは，一 部の行路案に限定して集合被覆問題を解くことでこの問題を 回避しているが, 乗務の総数が多くなるほど列生成子問題の 求解に時間がかかるといった側面をもつ.

一般に, 行路案作成には路線の規模や性質に合わせたアプ ローチが求められる，行路作成ではスケジュールの質と作成 時間が重視されるが，これらはトレードオフの関係にある.

高橋ら ${ }^{4)}$ は, 行路案を少数の乗務から構成される部分行路 を用いて段階的に作成する手法を提案している．部分行路の 作成を繰り返すことで問題の計算規模を縮小する一方, 部分 行路から構成される行路案に限定して全探索することで最適 化計算の負荷を抑えつつスケジュールの質の確保を図ってい る. しかし, 支線を有さない基地数が 1 駅の路線を対象とし ているため, 複雑な構造をもつ路線に対する手法の有効性は 未検証である。

Jütte $ら^{7)}$ は, グラフ分割手法 ${ }^{12)}$ と列生成法を用いて計算 量の削減に重きを置くアプローチを提案している，ヨーロッ パの大規模な路線に適用するにあたり, 乗務を複数の部分集 合にグラフ分割することで, 列生成子問題の計算量の削減を 図っている.

\section{3. 乗務員スケジュールの作成方法}

\section{1 提案手法の概要}

本章では，高橋らによって提案された部分行路を用いる手 


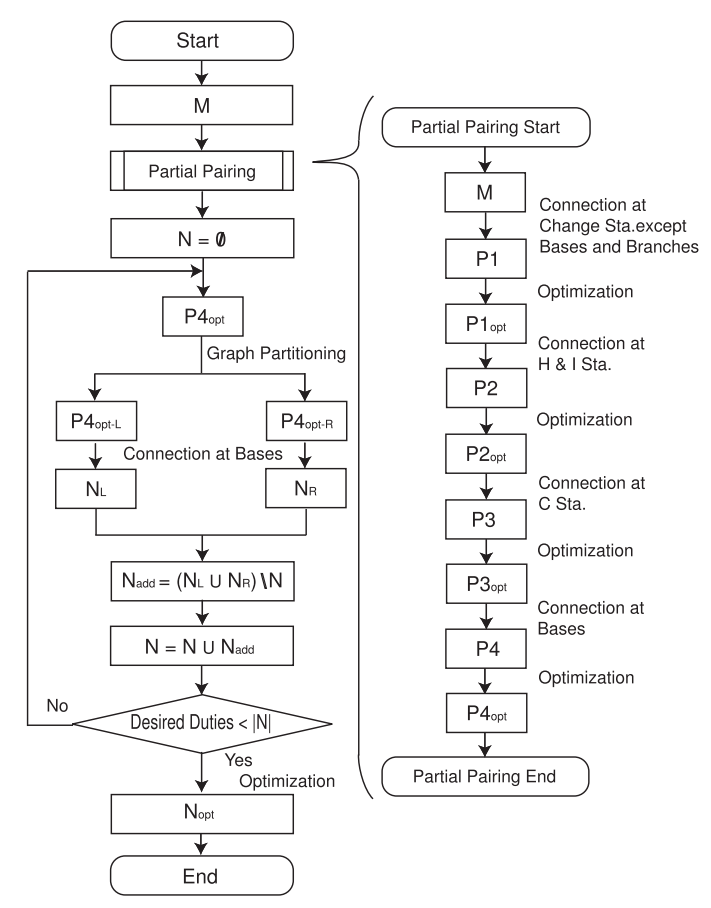

Fig. 2 Proposal method

法に, 便乗を効率的に割り当てる Graves らの定式化と Jütte らが用いたグラフ分割を導入した新しい行路案作成手法を提 案する。 なお，支線と複数基地への対応については，4 章で その詳細を述べる。

部分行路は問題の計算規模を縮小する一方で, 部分行路を 単位とした便乗が発生する問題がある。便乗を担当する乗務 員の稼働効率を鑑みた場合，便乗距離や便乗時間が短い部分 行路に便乗を割り当てることが望ましい。そこで，このよj な部分行路に対して効果的に便乗を割り当てるアプローチと して Graves らにより定式化されたペナルティ付き集合分割 問題を導入する (3.2 節)。 また，大規模な路線に部分行路を 用いる手法を適用した場合，作成される行路案数が数百万以 上にのぼることから，グラフ分割を導入することで全探索に よる探索時間と作成される行路案数の削減を試みる.

本章が提案する 5 段階の最適化計算により乗務員スケジュー ルを作成する新しい手法について，その概略を Fig. 2 に示 す. Fig. 2 において, |・| は集合の要素数を表わすものとす る. 最終的な乗務員スケジュールを求める手順の概要は下記 のとおりである.

(0) 乗務集合 $M$ の作成

対象とする運行ダイヤを交代可能駅で分割することによ り乗務の集合 $M$ を求める.

(1) 部分行路案集合 $P 1$ の作成と最適化 (3.2 節, 3.3 節, 4.2 節)

開始駅と終了駅を基地（ $\mathrm{E}, \mathrm{G}, \mathrm{N}$ 駅）または分岐駅 $(\mathrm{C}$, $\mathrm{H}$ ， I 駅）とする部分行路案を， $M$ に含まれる 1〜 5 個の乗 務を組み合わせることで作成する。作成は全探索を用いて 行なう. 乗務 $i \rightarrow j$ の接続は, $i$ の到着駅と $j$ の出発駅が
基地と分岐駅を除いた交代可能駅の場合に結合する．得ら れた部分行路案集合を $P 1$ で表わす. 目的関数值 $z$ が最小 となる部分行路集合 $P 1_{\mathrm{opt}} \subset P 1$ をぺナルティ付き集合分 割問題を解くことで求める.

(2) 部分行路案集合 $P 2$ の作成と最適化 (3.2 節, 3.3 節) 開始駅と終了駅を基地または分岐駅 (C 駅) とする部分 行路案を, $P 1_{\mathrm{opt}}$ に含まれる $1 \sim 6$ 個の部分行路を組み合わ せることで作成する．作成は全探索を用いて行なう。部分 行路 $i \rightarrow j$ の接続は, $i$ の到着駅と $j$ の出発駅が分岐駅の $\mathrm{H}$ 駅あるいは I 駅の場合に結合する，得られた部分行路案 集合を $P 2$ で表わす. 目的関数值 $z$ が最小となる部分行路 集合 $P 2_{\mathrm{opt}} \subset P 2$ をペナルティ付き集合分割問題を解くこ とで求める.

(3) 部分行路案集合 $P 3$ の作成と最適化 (3.2 節, 3.3 節) 開始駅と終了駅を基地とする部分行路案を， $P 2_{\mathrm{opt}}$ に含 まれる 1〜6 個の部分行路を組み合わせることで作成する. 作成は全探索を用いて行なう. 部分行路 $i \rightarrow j$ の接続は, $i$ の到着駅と $j$ の出発駅が分岐駅の $\mathrm{C}$ 駅の場合に結合する. 得られた部分行路案集合を $P 3$ で表わす. 目的関数值 $z$ が 最小となる部分行路集合 $P 3_{\mathrm{opt}} \subset P 3$ をペナルティ付き集 合分割問題を解くことで求める.

（4）部分行路案集合 $P 4$ の作成と最適化 (3.2 節, 3.3 節, 4.3 節)

開始駅と終了駅を基地とする中規模の部分行路案を, $P 3_{\mathrm{opt}}$ に含まれる $1 \sim 3$ 個の部分行路を組み合わせることで作成 する．作成は全探索を用いて行なう．部分行路 $i \rightarrow j$ の接 続は, $i$ の到着駅と $j$ の出発駅が基地の場合に結合する. 得 られた部分行路案集合を $P 4$ で表わす. 目的関数值 $z$ が最 小となる部分行路集合 $P 4_{\mathrm{opt}} \subset P 4$ をペナルティ付き集合 分割問題を解くことで求める.

(5) 行路案集合 $N$ の作成と最適化 (3.4 節)

最終的な行路案を，P4 opt に含まれる $1 \sim 7$ 個の部分行路 を組み合わせることで作成する。初期行路案集合を $N=\emptyset$ とする.はじめに, グラフ分割を用いて $P 4_{\mathrm{opt}}$ を 2 つの部分 集合 $P 4_{\mathrm{opt}-L}, P 4_{\mathrm{opt}-R}$ に分割する．作成は得られた部分集 合ごとに全探索を用いて行なう。P $4_{\mathrm{opt}-L}$ から作成される行 路案集合を $N_{L}, P 4_{\mathrm{opt}-R}$ から作成される行路案集合を $N_{R}$ で表わす。追加する行路案集合を $N_{\mathrm{add}}=\left(N_{L} \cup N_{R}\right) \backslash N$ とする。このとき, $N=N \cup N_{\text {add }}$ として行路案集合 $N$ を更新する. 行路案集合 $N$ に $P 4_{\mathrm{opt}}$ のすべての部分行路 が含まれ，所望の行路案数を得るまで，再度 $P 4_{\mathrm{opt}}$ をグラ フ分割して繰り返し行路案を追加する。目的関数值 $z$ が最 小となる行路集合 $N_{\mathrm{opt}} \subset N$ をペナルティ付き集合分割問 題を解くことで求める.

\section{2 部分行路案集合の作成}

各段階の条件を満たす部分行路案を作成する．作成は深さ 優先探索法を用いて行なう。乗務（あるいは部分行路）の接 続関係は頂点を乗務（あるいは部分行路），辺を乗務（あるい は部分行路）間の接続とする有向グラフで表現し，下記の条 
件を満たすとき乗務（あるいは部分行路） $i \rightarrow j$ は接続可能 であるものとする。

1) $i$ の到着駅と $j$ の出発駅が同一

2) $i \rightarrow j$ の接続時間は乗り継ぎ時間の範囲内

制約条件の上下限值は，Fig. 1 の路線で実際に運用されて いるスケジュールを基に設定する．P4 opt では開始駅と終了 駅を基地とする部分行路が最終的に得られるが，この基地に 着目した部分行路作成は, 以下に述べる理由から行路案の質 の劣化を抑制する可能性を有する.

乗務から部分行路へ問題の計算規模を縮小すると, 部分行 路を構成する乗務の接続関係は部分行路を頂点とするグラフ に縮約される。これにより頂点と辺の総数が減少し探索時間 が削減される一方，探索により得られる行路案の質が劣化す る可能性がある。そこで, 乗務員の休息が行なわれるために 乗り継ぎ時間の上限が長く設定されている基地では，接続可 能な乗務（辺）の総数が多くなることに注目する．行路案の 質を確保するためには行路案作成において基地での接続に関 する選択肢が多いことが望ましい。そこで，部分行路作成で は基地を除いた交代可能駅で接続することで，接続可能な部 分行路の総数を十分に残す.

また，部分行路から構成される行路案の開始駅と終了駅は おのずと基地となる. 先行研究 ${ }^{4)}$ のように基地が 1 駅の路線 では，これらの部分行路から構成される行路案は出退勤駅の 同一性をおのずと満たす。しかし，複数基地に適用するため には改良を加える必要がある(4.3 節).

\section{3 部分行路案集合の最適化}

本章で提案する手法は，2.3 節で述べた集合被覆問題を解 く代わりに，効果的な便乗選択の実現を目的に Graves ら ${ }^{6)}$ により定式化されたペナルティ付き集合分割問題を解くこと で部分行路を作成する。これは，目的関数に集合分割問題に おける制約条件の違反度を表わす重み付きペナルティを加え るペナルティ関数法に基づく定式化である.

$y_{i}$ を $i$ 番目の乗務（あるいは部分行路）の便乗数（ペナル ティ), $d_{i}$ をペナルティの重みとする.このとき, ペナルティ 付き集合分割問題は $(4) \sim(7)$ 式で記述される.

$$
\begin{array}{lll}
\min & z=\sum_{j \in N} c_{j} x_{j}+\sum_{i \in M} d_{i} y_{i} & \\
\text { s.t. } & \sum_{j \in N} a_{i j} x_{j}-y_{i}=1, & \forall i \in M \\
& x_{j} \in\{0,1\}, & \forall j \in N \\
& y_{i} \geq 0, & \forall i \in M
\end{array}
$$

（5）式は各乗務（あるいは部分行路）に 1 組以上の乗務員を 割り当てる制約条件を表わす。(6) 式は部分行路案 $j$ の採否 （1または 0) を表わす整数制約を，(7) 式は $i$ 番目の乗務（あ るいは部分行路）の便乗数が非負の整数であることを表わす. 運転距離が短い乗務（あるいは部分行路）に対して, 効果的 に便乗を発生させるようにペナルティの重み $d_{i}$ を運転距離と する．本稿では，目的関数值 $z$ として (4) 式の代わりに部分
行路数, 乗り継ぎ回数, および便乗距離の重み付き和である (8) 式を用いる.

$$
z=\alpha \sum_{j \in N} x_{j}+\beta \sum_{j \in N} c_{j} x_{j}+\sum_{i \in M} d_{i} y_{i}
$$

ここで， $c_{j}$ は部分行路案 $j$ の乗り継ぎ回数とする. (8) 式に おける第 1 項は採用される部分行路数, 第 2 項は採用される 部分行路に含まれる総乗り継ぎ回数, 第 3 項は総便乗距離を 表わす. 最適化では総便乗距離の最小化を重視し, 重み $\alpha$ と $\beta$ は以下のように調整する。

1) $P 1 \sim P 3$ の最適化では, $\alpha=0, \beta=10^{-n}$ とし, 目的関数 $z$ の小数第一位以上が総便乗距離, 小数第二位以下が総乗り 継ぎ回数となるように $n$ を設定する．乗り継ぎ回数を評価関 数に含めることで，実際の車両運用に近い効率的な人員配置 の実現を図る。

2) $P 4$ と $N$ の最適化では, $\alpha=10^{-n}, \beta=0$ とし, 目的関 数 $z$ の小数第一位以上が総便乗距離，小数第二位以下が採用 される部分行路数となるように $n$ を設定する。採用される部 分行路数を評価関数に含めることで，Nにおける計算規模の 縮小を図る.

\section{4 グラフ分割を用いた行路案作成}

グラフ分割を用いてスケジュールとしての質が低い行路案 を除外することで，行路案数と探索時間の削減を図る。乗務 員の乗り継ぎ時間が長いほど勤務効率は悪化すると考え，そ のような部分行路の接続関係を禁止するようにグラフ分割を 行なう。

(1) グラフ分割問題

頂点 $v \in V$, 有向辺 $(i, j) \in E$, 辺重み $w_{i j}$ をもつグラ フ $G=(V, E)$ を考える. このとき, 頂点 $V$ の分割 $\{L, R\}$ とは, $L \cap R=\emptyset, L \cup R=V$ を満たす頂点の部分集合の 対を意味する.グラフ分割問題とは， $L$ と $R$ によりカット された辺 (カットエッジ) の辺重み和 $w_{c}$ を最小にする分割 $G_{p}=\{L, R\}$ を求める問題である.

$$
w_{c}:=\sum_{(i, j) \in E: i \in L, j \in R} w_{i j}+\sum_{(i, j) \in E: i \in R, j \in L} w_{i j}
$$

Jütte $~^{7)}$ はグラフ分割問題を乗務員スケジューリング問題 へ適用するにあたり，下記を提案している。

(1-a) 辺重みの設定

部分行路 $i \rightarrow j$ の接続において, $A_{i}^{t}$ を $i$ の到着時刻, $D_{j}^{t}$ を $j$ の出発時刻とする。このとき, 乗務員の乗り継ぎ時間 $D_{j}^{t}-A_{i}^{t}$ が長いときに辺重みが小さくなるように，乗り継ぎ時間の逆 数をとる.

$$
w_{i j}^{\prime}=\frac{1}{D_{j}^{t}-A_{i}^{t}}
$$

乗り継ぎ時間のほかに頂点からの辺数を考慮して, 辺数が最 小の頂点に対する辺重みを大きく設定する．グラフ分割では (11) 式に示す辺重みを用いる. 


$$
w_{i j}=\frac{w_{i j}^{\prime}}{\min \left(\sum_{k \in V:(i, k) \in E} w_{i k}^{\prime}, \sum_{k \in V:(k, j) \in E} w_{k j}^{\prime}\right)}
$$

(1-b) 分割サイズの設定

グラフ分割問題を乗務員スケジューリング問題へ適用する にあたり，必ずしも部分集合の頂点数が等しくなるように分 割する必要はない。そこで, 分割のサイズに最大許容範囲を 与える. 最大許容範囲は, 部分集合の最大の頂点数と部分集 合の最小の頂点数により (12) 式のように決定する.

$$
\operatorname{range}\left(G_{p}\right)=\frac{\max (|L|,|R|)}{\min (|L|,|R|)}
$$

(2) グラフ分割アルゴリズム

グラフ分割手法には GGGP (Greedy Graph Growing Partitioning) ${ }^{12)}$ を用いる. GGGP はヒューリスティックな解法 で，ランダムに選択された頂点からカットエッジの辺重み和 を小さくする頂点を繰り返し選択することによりグラフを分 割する。この際，異なる頂点からの開始は異なる分割をもた らすため, GGGP により得られるグラフ分割は頂点の選択に 依存する。接続する頂点をある程度ランダムに選択するのが 本質的で，分割により得られるグラフそのものは大きな意味 をもたない

ランダムに選択された頂点を $v_{s} \in V$ とする. GGGP で は, グラフ分割を $L=\left\{v_{s}\right\}, R=V \backslash\left\{v_{s}\right\}$ となる分割 $G_{p}=\{L, R\}$ から開始する.つぎに選択する頂点 $v_{t} \in R$ を (13) 式の頂点ゲインにより求める.

$$
\begin{aligned}
g\left(v_{t}\right)= & \sum_{i \notin R:(i, j) \in E} w_{i j}+\sum_{i \notin R:(i, j) \in E} w_{j i} \\
& -\sum_{i \in R:(i, j) \in E} w_{i j}-\sum_{i \in R:(i, j) \in E} w_{j i}
\end{aligned}
$$

頂点ゲイン $g\left(v_{t}\right)$ は, $R$ に割り当てられている頂点 $v_{t}$ を $L$ へ 移動するときのカットエッジの辺重み和の更新を表わしてい る. $g\left(v_{t}\right)>0$ とき, $v_{t}$ を $L$ に移動するとカットエッジの辺重 み和は $g\left(v_{t}\right)$ だけ減少する。ここで, 最大の $g\left(v_{t}\right)\left(g\left(v_{t}\right)<0\right.$ でも可能とする）をもつ頂点 $v_{t} \in R$ を $L$ へ移動する. $L$ の 頂点数が少なくとも $1 / \operatorname{range}\left(G_{p}\right) \cdot|V \backslash L|$ となるまで，この 手順を繰り返す。最後に, $L$ の頂点数が $\operatorname{range}\left(G_{p}\right) \cdot|V \backslash L|$ を 超えていないとき， $g\left(v_{t}\right)>0$ 満たす頂点を $L$ へ移動する. $g\left(v_{t}\right)>0$ を満たす限り,この手順を繰り返す.

(3) 行路案の作成

初期行路案集合を $N=\emptyset$ とする．部分行路集合 $P$ にグラフ 分割を用いて 2 つの部分集合 $P_{L}, P_{R}$ に分割する．行路案の作 成は得られた部分集合ごとに全探索を用いて行なう。 $P_{L}$ から 作成される行路案集合を $N_{L}, P_{R}$ から作成される行路案集合を $N_{R}$ で表わす．追加する行路案集合を $N_{\text {add }}=\left(N_{L} \cup N_{R}\right) \backslash N$ とする.このとき， $N=N \cup N_{\text {add }}$ として行路案集合 $N$ を 更新する。 GGGP のランダム性から作成される行路案が毎 回異なる性質を利用して，行路案集合 $N$ に $P$ のすべての部
分行路が含まれ, 所望の行路案数を得るまで, 再度 $P$ をグラ フ分割して繰り返し追加する。

\section{4. 支線と複数基地への対応}

\section{1 部分行路作成手法の改良}

本稿では, 乗務の総数が先行研究 ${ }^{4)}$ の 10 倍程度で 3 支線と 3 基地を有する大規模かつ複雑な構造をもつ路線を対象とす

る，そこで，高橋ら ${ }^{4)}$ の手法では考慮されていなかった支線 と複数基地のそれぞれについて手法を改良する．以下，4.2 節 では支線に対する改良を，4.3 節では複数基地に対する改良 を述べる。

\section{2 支線に対する部分行路作成の改良}

支線を有する路線に対して，開始駅と終了駅を基地とする 部分行路案を一度に作成するのは多大な計算量を要する。こ れは，本線から支線へ分岐する起点である分岐駅からの探索 パターンが増加することにより，探索範囲が広がるためであ る。そこで，分岐駅に着目した部分行路作成手法を考える。

はじめに，開始駅と終了駅を基地または分岐駅とする部分 行路を $P 1$ で作成する。 $P 1$ では分岐駅を経由する探索を行 なわないことで，計算量の削減を図っている，つぎに，得ら れた部分行路を分岐駅 $(P 2: \mathrm{H}$ 駅あるいは I 駅, $P 3: \mathrm{C}$ 駅 $)$ で結合することにより，開始駅と終了駅を基地とする部分行 路を作成する，段階的な手順を経ることで，開始駅と終了駅 を基地とする部分行路が少ない計算量で作成可能となる.

\section{3 複数基地に対する部分行路作成の改良}

複数の基地を有する路線では，それぞれの基地を出退勤駅 とする行路案を作成することが求められる．高橋 ${ }^{4)}$ の手法を 適用する場合，出退勤駅の同一性をどの段階で考慮するかを 決める必要がある。P4 における部分行路の作成で出退勤駅の 同一性を考慮する場合， 3 パターン（開始駅と終了駅が $\mathrm{E}-\mathrm{E}$ 駅， G-G 駅，N-N 駅）の部分行路が作成される．3.2 節で述 ベた接続条件 1)より，異なるパターンの部分行路には接続不 可能であることから，同じパターンの部分行路を組み合わせ ることでしか行路案を作成できず，作成される行路案は必要 以上に限定される。P4における部分行路の作成で出退勤駅 の同一性を考慮しない場合，9 パターン（開始駅と終了駅が E-E 駅, E-G 駅, E-N 駅, G-E 駅, G-G 駅, G-N 駅, N-E 駅, N-G 駅, N-N 駅) の部分行路が作成される. パターン 数の増加にともなって, 部分行路間の接続における自由度が 増し，さまざまな部分行路を組み合わせた行路案の作成が可 能となる．このことを鑑み，出退勤駅の同一性については $N$ における行路案作成で考慮する。

\section{5. 数 值 実 験}

\section{1 対象とする路線の詳細}

数值実験で対象とする路線の概略図は Fig. 1 に示したとお りである. 列車種別の運行区間を Table 1 に示す. Table 1 において，。は運行する列車種別を表わしている。たとえば， $\mathrm{A}-\mathrm{H}-\mathrm{L}$ は本線 $(\mathrm{A}-\mathrm{H})$ と支線 $2(\mathrm{H}-\mathrm{L})$ からなる運行区間て 
Table 1 Train type for service section

\begin{tabular}{c|c|c|c|c|c|c}
\hline Section & Local & $\begin{array}{c}\text { Limited } \\
\text { express1 }\end{array}$ & $\begin{array}{c}\text { Limited } \\
\text { express2 }\end{array}$ & $\begin{array}{c}\text { Limited } \\
\text { express3 }\end{array}$ & $\begin{array}{c}\text { Limited } \\
\text { express4 }\end{array}$ & $\begin{array}{c}\text { Out of } \\
\text { service }\end{array}$ \\
\hline A-J & 0 & 0 & & & & 0 \\
A-C-K & 0 & & 0 & 0 & & \\
A-H-L & 0 & & & & & 0 \\
A-I-N & 0 & 0 & 0 & & 0 & 0 \\
N-P & & 0 & 0 & & 0 & 0 \\
K-C-H-L & 0 & 0 & & & & \\
K-C-I-N & 0 & 0 & 0 & & & \\
K-C-J & 0 & 0 & & & & \\
\hline
\end{tabular}

あり，そこでは普通と回送が運行している，運行区間におけ る通過駅と停車駅は下記のとおりである.

1) 普通：すべての交代可能駅に停車

2) 特急 $1: M$ 駅を通過

3) 特急 $2: E, M$ 駅を通過

4) 特急 $3: \mathrm{C}$ 駅を通過

5) 特急 $4:$ C, D, E, F, M 駅を通過

6) 回送：A 駅を通過

対象とする運行ダイヤを交代可能駅で分割することにより 得られる乗務の総数は 6656 個である. 行路は下記の 5 種類 に分けられる。

1）日勤 $1: 6: 00 ９: 30$ ごろに乗務を開始，12:00～17:00 ご ろに乗務を終了.

2）日勤 $2: 13: 00 １ 7: 00$ ごろに乗務を開始，20:30～24:00 ごろに乗務を終了.

3）日勤 $3: 6: 00 〜 12: 30$ ごろに乗務を開始，17:00〜 24:00 ごろに乗務を終了。

4) 泊り明け $1 ： 16: 00 〜 19: 00$ ごろに乗務を開始，翌日の 7:30〜10:30 ごろに乗務を終了.

5) 泊り明け $2: 18: 00 \sim 20: 30$ ごろに乗務を開始，翌日の 6:30〜8:30 ごろに乗務を終了.

行路の満たすべき労働条件は下記のとおりである.

1) 行路の開始駅と終了駅は同一の基地

2) 乗り継ぎ時間の上下限

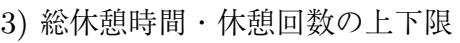

4）勤務時間の上下限

5) 総運転距離の上下限

6) 連続運転時間・連続運転距離の上限

7) 仮眠時間の上下限

8) 宿泊人数の上限

本線における労働条件の上下限值を Table 2 に示す．P1 $P 4$ の作成では, 労働条件 2) 8) を考慮する，なお，部分行 路の作成において 3)〜 5) に関しては上限制約だけを考える. 3)～5) の下限制約は行路案作成（3.4 節）において満たせば 良いことから部分行路作成では考慮しない

\section{2 実験結果}

数值実験における計算環境を Table 3 に示す。(8) 式の目 的関数における重みは Table 4 のとおりである．提案手法に よる自動作成結果と実運用データとの比較を Table 5 に示
Table 2 Parameters of labor regulations

\begin{tabular}{c|c|c|c|c|c}
\hline & $P 1$ & $P 2$ & $P 3$ & $P 4$ & $N$ \\
\hline Working time & $0 \sim 2 \mathrm{~h}$ & $0 \sim 3 \mathrm{~h}$ & $\begin{array}{c}6.25 \sim \\
12.25 \mathrm{~h}\end{array}$ \\
\hline Break time & $0 \sim 0.5 \mathrm{~h}$ & $0 \sim 0.75 \mathrm{~h}$ & $\begin{array}{r}0.75 \sim \\
3 \mathrm{~h}\end{array}$ \\
\hline $\begin{array}{c}\text { Number of } \\
\text { break times }\end{array}$ & \multicolumn{2}{|c|}{$0 \sim 1$} & $0 \sim 3$ & $1 \sim 12$ \\
\hline $\begin{array}{c}\text { Operational } \\
\text { distance }\end{array}$ & \multicolumn{3}{|c|}{$0 \sim 350 \mathrm{~km}$} & $\begin{array}{c}150 \sim \\
350 \mathrm{~km}\end{array}$ \\
\hline $\begin{array}{c}\text { Continuous } \\
\text { operational time }\end{array}$ & \multicolumn{3}{|c}{$0 \sim 2.3 \mathrm{~h}$} \\
\hline $\begin{array}{c}\text { Continuous } \\
\text { operational distance }\end{array}$ & \multicolumn{4}{|c}{$0 \sim 80 \mathrm{~km}$} \\
\hline Sleeping time & \multicolumn{3}{c}{$4.75 \sim 6.5 \mathrm{~h}$} \\
\hline
\end{tabular}

Table 3 Experimental environment

\begin{tabular}{c|c}
\hline Development environment & Windows10 64 bit, MATLAB R2016a \\
\hline CPU & Core i7-7700 $(3.60 \mathrm{GHz})$ \\
\hline Memory & $32.0 \mathrm{~GB}$ \\
\hline IP solver & Gurobi $7.5^{13)}$ \\
\hline
\end{tabular}

Table 4 Coefficients

\begin{tabular}{c|c|c|c|c|c}
\hline & $P 1$ & $P 2$ & $P 3$ & $P 4$ & $N$ \\
\hline$\alpha$ & 0 & 0 & 0 & $10^{-8}$ & $10^{-4}$ \\
\hline$\beta$ & $10^{-8}$ & $10^{-8}$ & $10^{-8}$ & 0 & 0 \\
\hline
\end{tabular}

Table 5 Result of experiment

\begin{tabular}{c|c|c}
\hline & Actual data & Result \\
\hline Number of duties & 201 & 182 \\
\hline Total of deadheading distance & $1519.7 \mathrm{~km}$ & $630.1 \mathrm{~km}$ \\
\hline Number of deadheads & 226 & 112 \\
\hline Calculation time & - & About $3 \mathrm{~h}$ \\
\hline
\end{tabular}

Table 6 Partial pairings in $P 1, P 2, P 3$ and $P 4$

\begin{tabular}{c|c|c|c|c}
\hline & $P 1$ & $P 2$ & $P 3$ & $P 4$ \\
\hline$|P|$ & 23982 & 8101 & 149791 & 7102 \\
\hline$\left|P_{\text {opt }}\right|$ & 3778 & 2542 & 1659 & 843 \\
\hline Total of & 92.2 & 100.0 & 244.2 & 244.2 \\
deadheading distance & $\mathrm{km}$ & $\mathrm{km}$ & $\mathrm{km}$ & $\mathrm{km}$ \\
\hline Number of deadheads & 16 & 20 & 44 & 44 \\
\hline Generation time & $30 \mathrm{~s}$ & $16 \mathrm{~s}$ & $226 \mathrm{~s}$ & $8 \mathrm{~s}$ \\
\hline Optimization time & $1 \mathrm{~s}$ & $4 \mathrm{~s}$ & $1694 \mathrm{~s}$ & $5 \mathrm{~s}$ \\
\hline
\end{tabular}

す。また，自動作成したスケジュール内容を Fig. 3 に，実際 に運用されているスケジュール内容を Fig. 4 に示す. Fig. 3, 4 において, 縦軸は行路番号, 横軸は時刻を表わす。棒グラフ 中の赤色の部分が乗務, 黒色の部分が乗り継ぎ時間を示してい る. 提案手法では Table 5 に示されるように, 実運用デー夕 と比べて行路数を 201 から 182 まで，便乗距離を $1519.7 \mathrm{~km}$ から $630.1 \mathrm{~km}$ まで，便乗数を 226 から 112 まで削減したス ケジュールが短時間で自動作成されたことがわかる.

部分行路の作成結果を Table 6 に示す. Table 6 からわ かるように，部分行路の作成を繰り返すことで，6656 個の乗 務は最終的に 843 個の部分行路に縮約される。 また, ペナル ティ付き集合分割問題を解くことで，便乗距離の少ない部分 行路が得られたことがわかる。これにより，最終的な乗務員 


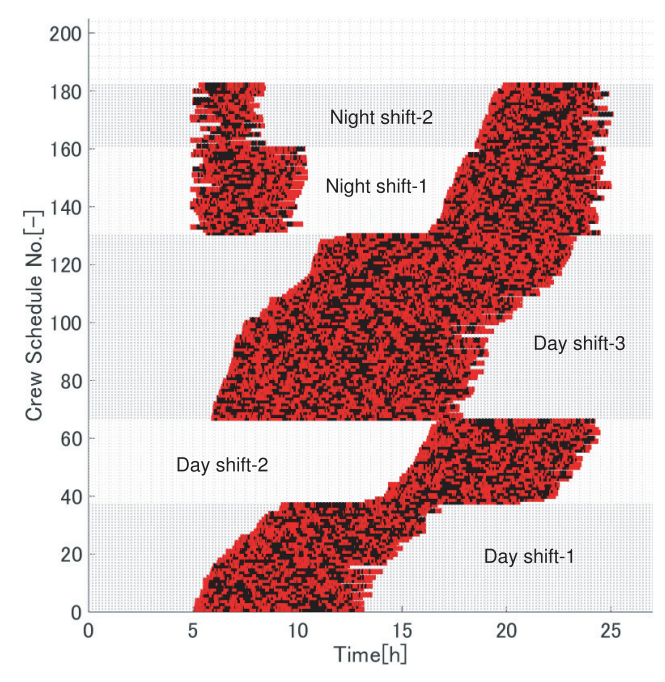

Fig. 3 Result of crew schedule

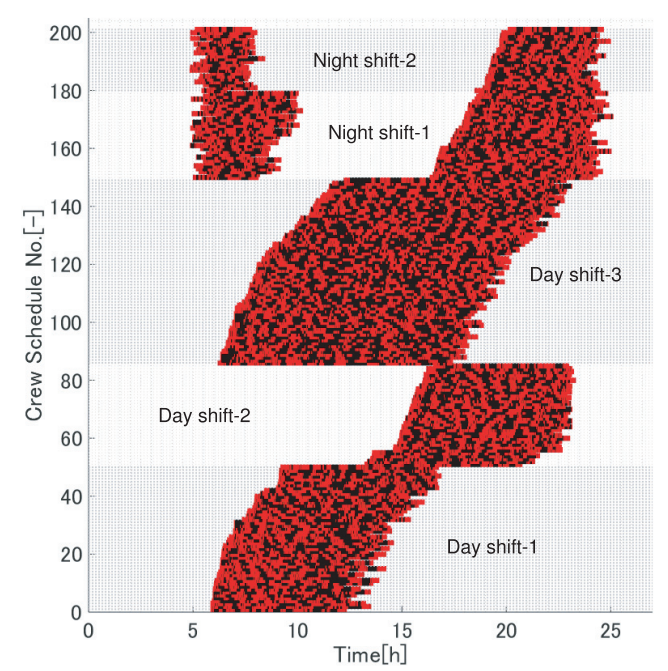

Fig. 4 Actual crew schedule

Table 7 Duties in $N$

\begin{tabular}{c|c|c}
\hline Graph partitioning & $\circ$ & $\times$ \\
\hline$|N|$ & 1581965 & 6455249 \\
\hline$\left|N_{\text {opt }}\right|$ & 182 & - \\
\hline Total of deadheading distance & $630.1 \mathrm{~km}$ & - \\
\hline Number of deadheads & 112 & - \\
\hline Generation time & $1.2 \mathrm{~h}$ & $11.2 \mathrm{~h}$ \\
\hline Optimization time & $1.1 \mathrm{~h}$ & $24 \mathrm{~h}$ \\
\hline
\end{tabular}

スケジュールにおける便乗距離の大幅な削減に繋がったと考 えられる。

グラフ分割の有効性を確認した結果を Table 7 に示す。ま た, Table 8 にグラフ分割の詳細結果を示す。グラフ分割を 用いる場合は行路案作成時間が $11.2 \mathrm{~h}$ から $1.2 \mathrm{~h}$ まで短縮さ れる一方で, 用いない場合では行路案数の多さから実行可能 解を得ることができなかった（最適化計算は 24 時間で打ち 切り). Table 8 に示すように, 本数值実験ではグラフ分割を 5 回繰り返すことで行路案を作成した。グラフ分割のランダ 厶性から各回において十分な $\left|N_{\text {add }}\right|$ を得られていることがわ
Table 8 Duties generated by graph partitioning in $N$

\begin{tabular}{c|c|c|c|c|c}
\hline Count & 1 & 2 & 3 & 4 & 5 \\
\hline$\left|P 4_{\text {opt }-L}\right|$ & 422 & 422 & 422 & 422 & 422 \\
\hline$\left|P 4_{\text {opt }-R}\right|$ & 421 & 421 & 421 & 421 & 421 \\
\hline$\left|N_{L}\right|$ & 218161 & 194562 & 144797 & 298789 & 140844 \\
\hline$\left|N_{R}\right|$ & 217626 & 343714 & 205225 & 289560 & 208325 \\
\hline$\left|N_{L} \cup N_{R}\right|$ & 435787 & 538276 & 350022 & 588349 & 349169 \\
\hline$\left|N_{\text {add }}\right|$ & 435787 & 474879 & 192221 & 303337 & 175741 \\
\hline$|N|$ & 435787 & 910666 & 1102887 & 1406224 & 1581965 \\
\hline $\begin{array}{c}\text { Generation } \\
\text { time }\end{array}$ & $837 \mathrm{~s}$ & $1043 \mathrm{~s}$ & $681 \mathrm{~s}$ & $1132 \mathrm{~s}$ & $686 \mathrm{~s}$ \\
\hline
\end{tabular}

かる．以上より，部分行路とグラフ分割を用いた提案手法は 解の質と計算量の観点から有効であるといえる.

\section{6. おわりに}

本稿では，高橋らによって提案された部分行路を用いる行 路案作成手法に, Gravesらにより定式化されたペナルティ付 き集合分割問題，Jütte らが用いたグラフ分割，および支線 と複数基地に関する従来手法の改良を導入した新しい行路案 作成手法を提案した.

数值実験では，提案手法により自動作成したスケジュール が，実際に運用されているスケジュールと比べて解の質と計 算量の観点から優れていることを確認した。 今後の課題とし て, 勤務時間や休鄎時間の分散の最小化といった，乗務員の 負担を考慮したスケジュールの作成や，ほかの大規模かつ複 雑な路線を対象とした数值実験を行ない, 手法の有効性を確 認することがあげられる。

\section{参 考 文 献}

1）今泉 淳：鉄道における資源の使用計画に対する最適化アプ ローチ—乗務員と車両に対するスケジューリング—, 経営論 集, 72,43/55 (2008)

2) 富井規雄 : 鉄道のスケジューリングアルゴリズム : 現状と今後 の課題，オペレーションズ・リサーチ，49-1，33/39 (2004)

3）今泉, 福村, 森戸 : 鉄道乗務員スケジューリング問題に対する 解法とその評価, 経営論集, 71, 125/139 (2008)

4）高橋, 渡邊:段階的な最適化計算による鉄道乗務員スケジュール の自動作成，計測自動制御学会論文集，53-2, 162/168 (2017)

5）鎌田, 高橋, 山迫, 渡邊: 段階的な最適化計算による鉄道乗務 員スケジュールの自動作成一急行列車と各駅停車が混在する路 線への適用一，自動制御連合講演会講演論文集，59,124/125 (2016)

6) G.W. Graves, R.D. McBride, I. Gershkoff, D. Anderson and D. Mahidhara: Flight Crew Scheduling, Management Science, 39-6, 736/745 (1993)

7) S. Jütte and U.W. Thonemann: A Graph Partitioning Strategy for Solving Large-scale Crew Scheduling Problems, OR Spectrum, 37-1, 137/170 (2015)

8) A. Caprara, M. Fischetti and P. Toth: A Heuristic Method for the Set Covering Problem, Operations Research, 47-5, $730 / 743(1999)$

9）今泉，熟見，斎藤，森戸，富井，福村：鉄道乗務員運用計画一 のバックトラック法による行路候補列挙と集合被覆問題の近似 解法, 最適化：モデリングとアルゴリズム， 17, 172/179, 統 計数理研究所 (2004)

10）西，室井，乾口，高橋，片岡：実乗務制約を有する鉄道乗務 員運用計画問題に対する列生成法の適用, 電気学会論文誌 C, 
131-6, 1199/1208 (2011)

11) C. Barnhart, E.L. Johnson, G.L. Nemhauser, M.W.P. Savelsbergh and P.H. Vance: Branch-and-Price: Column Generation for Solving Huge Integer Programs, Operations Research, 46-3, 316/329 (1998)

12) G. Karypis and V. Kumar: A Fast and High Quality Multilevel Scheme for Partitioning Irregular Graphs, SIAM J. Sci. Comput., 20-1, 359/392 (1998)

13) Gurobi Optimizer: http://www.gurobi.com/

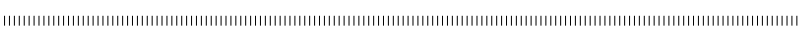

\section{[著 者 紹 介]}

鎌 田龍 太

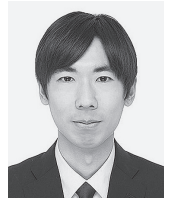

2017 年早稲田大学先進理工学部電気・情報生命 工学科卒業. 同年同大学大学院先進理工学研究科 電気・情報生命専攻に入学し, 現在に至る. 数理 計画アプローチによる鉄道乗務員スケジューリン グの研究に従事.

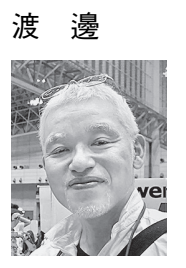

亮（正会員）

1989 年慶應義塾大学大学院修士課程修了. 95 年早稲田大学大学院博士課程修了. 89 年石川島播 磨重工業 (株) 入社, 98 年大阪大学助手, 同年講 師, 2002 年早稲田大学助教授, 2007 年同大学教授 となり現在に至る。ロバスト制御, 数理的モデリ ング，制御理論応用などの研究に従事. 博士（工 学). 97 年計測自動制御学会論文賞受賞. IEEE の会員. 